\title{
Successful Naloxone Administration During Cardiac Arrest in Course of Remifentanil Labor Analgesia: Case Report
}

\author{
Aboši Alexander ${ }^{1}$, Aboši Kateřina ${ }^{1}$, Klučka Jozef², Harazim Hana ${ }^{3}$, Kosinová Martina², \\ Štourač Petr²

\begin{abstract}
${ }^{1}$ Department of Anaesthesiology and Intensive Care Medicine, Sokolov Hospital, Sokolov, Czech Republic ${ }^{2}$ Department of Paediatric Anaesthesiology and Intensive Care Medicine, University Hospital Brno, Medical Faculty of Masaryk University, Brno, Czech Republic

${ }^{3}$ Department of Anaesthesiology and Intensive Care Medicine, University Hospital Brno, Medical Faculty of Masaryk University, Brno, Czech Republic
\end{abstract}

Background: Remifentanil for pain relief during labour is wide accepted alternative to epidural analgesia. The aim of this article is to highlight rare serious complication of labour analgesia with remifentanil and describe its solution in the hospital, where the use of remifentanil in childbirth is analgesic method of choice.

Case Report: 26-years old primigravida nullipara in the $39^{\text {th }}$ week of pregnancy, height $160 \mathrm{~cm}$, weight $70 \mathrm{~kg}\left(\mathrm{BMI} 29 \mathrm{~kg} / \mathrm{m}^{2}\right)$. History of three acute meningitis, two herpes infections and polyvalent allergy. During her adolescence, she contacted marihuana followed by 6 hours of unconsciousness. One year before becoming pregnant, she underwent short-term general anaesthesia as part of donating oocytes without complications. The pregnancy was uncomplicated.

After 7 hours during the first labor period analgesia was required. Blood pressure at the time of indication was $130 / 90 \mathrm{mmHg}$, pulse 116/min, $\mathrm{SpO}_{2}$ 95\%, and pain intensity according to VAS 8. Remifentanil administration was initiated at a rate of $80 \mu \mathrm{g} / \mathrm{hr}(3.2 \mathrm{~mL} / \mathrm{hr})$ without PCA boluses. After ten minutes of infusion, blood pressure was $115 / 75 \mathrm{mmHg}$, pulse $105 / \mathrm{min}$., $\mathrm{SpO}_{2} 94 \%$, and VAS decreased to 6-7. After 13 minutes of the infusion the obstetrician was called for loss of consciousness by partner. He called the anaesthesiological team. The parturient was cyanotic $\left(\mathrm{SpO}_{2}\right.$ not detected pulse), GCS 3, and the pulse was not palpable on the carotid arteries, and masseteric muscles rigidity were present. Administration of remifentanil was stopped immediately. Cardiopulmonary resuscitation was started and naloxone $0.4 \mathrm{mg}$ IV was administered.
Parturient awakened in tens seconds after administration of naloxone to full lucidity (GCS 15). Cardiac arrest was 3 minutes long. Acute caesarean section was performed in general anaesthesia without complications. The newborn was male, weighing $2730 \mathrm{~g}, 49 \mathrm{~cm}$ with Apgar score 10 - 10 - 10 . We computed plasmatic level of remifentanil during administration with maximum level of $0.6 \mathrm{ng} / \mathrm{mL}$ (TIVA trainer, Minto model). It didn't explain respiratory arrest of parturient.

Discussion: We attempted to objectify the cause of the cardiac arrest by simulating the estimated plasma $\left(\mathrm{C}_{\mathrm{pl}}\right)$ and effective tissue $\left(C_{e f}\right)$ concentrations of remifentanil in the application scheme usingthe Minto Model (TIVA Trainer software). The maximum calculated plasma and effective tissue levels of remifentanil were both $0.4 \mathrm{ng} / \mathrm{mL}$ at the fifteenth minute of initiation of administration (Fig. 1). This level is very distant from the level that, according to available literature, causes $50 \%$ depression of minute ventilation in healthy volunteers by Glass et al. $1.17 \mu \mathrm{g} / \mathrm{mL}(0.85-1.49 \mathrm{ng} / \mathrm{mL})$. For comparison, we also calculated the levels of remifentanil in the collateral cases described by Marr et al. $\left(\mathrm{C}_{\mathrm{pl}} 1.6-9.1 \mathrm{ng} / \mathrm{mL}, \mathrm{C}_{\text {ef }} 2.3-4.1 \mathrm{ng} / \mathrm{mL}\right)$ and Bonner et al. $\left(\mathrm{C}_{\mathrm{pl}} 2.2-10.0 \mathrm{ng} / \mathrm{mL}, \mathrm{C}_{\text {ef }} 3.2-4.9 \mathrm{ng} / \mathrm{mL}\right)$ (Fig. 2 and 3 ). In these cases, the peak concentrations of remifentanil were high and could explain respiratory depression, however they decreased significantly in the next 90 seconds.

Conclusion: Case report pointed out the need for availability of remifentanil antidote in the delivery room and on the importance of rapid availability of anaesthesiological team.

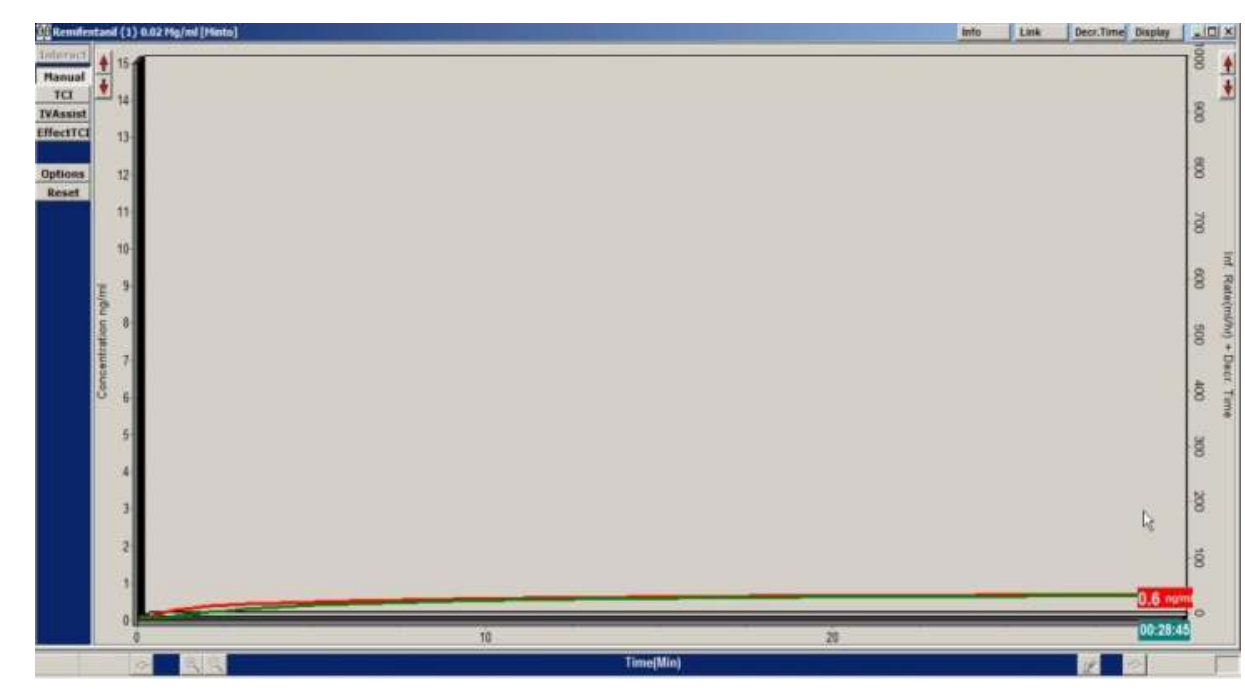

Figure 1) Plasmatic concentration (Minto model)

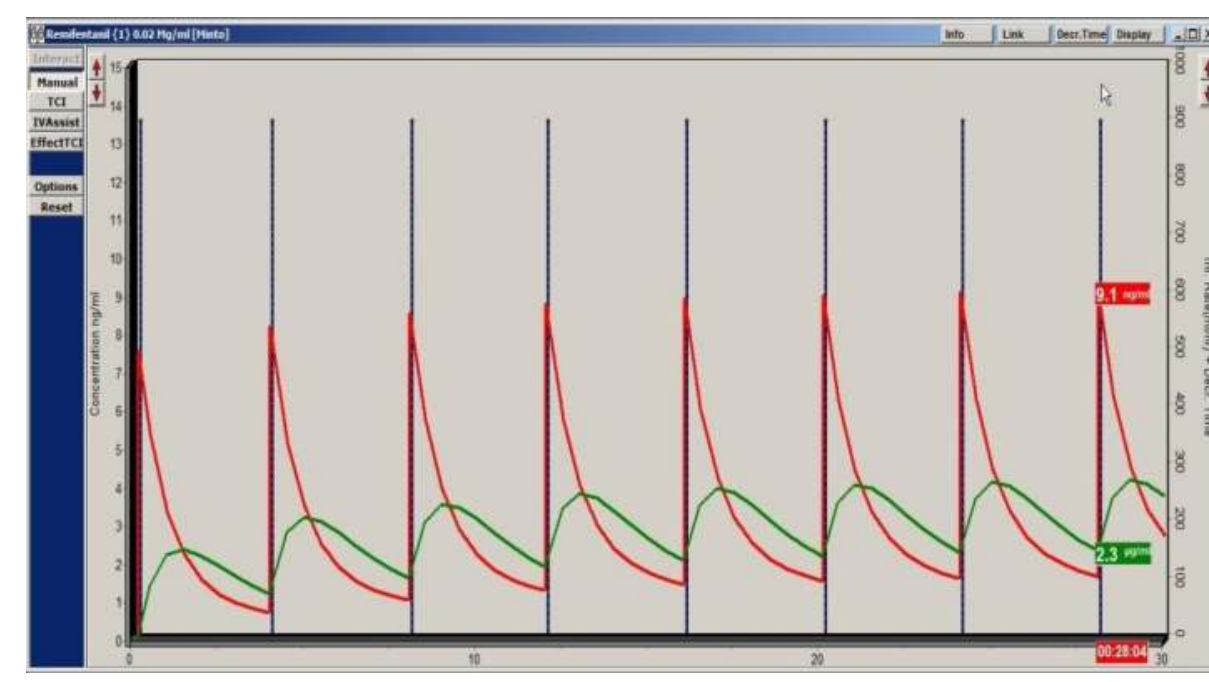

Figure 2) Plasmatic concentration Marr et al. (Minto model)

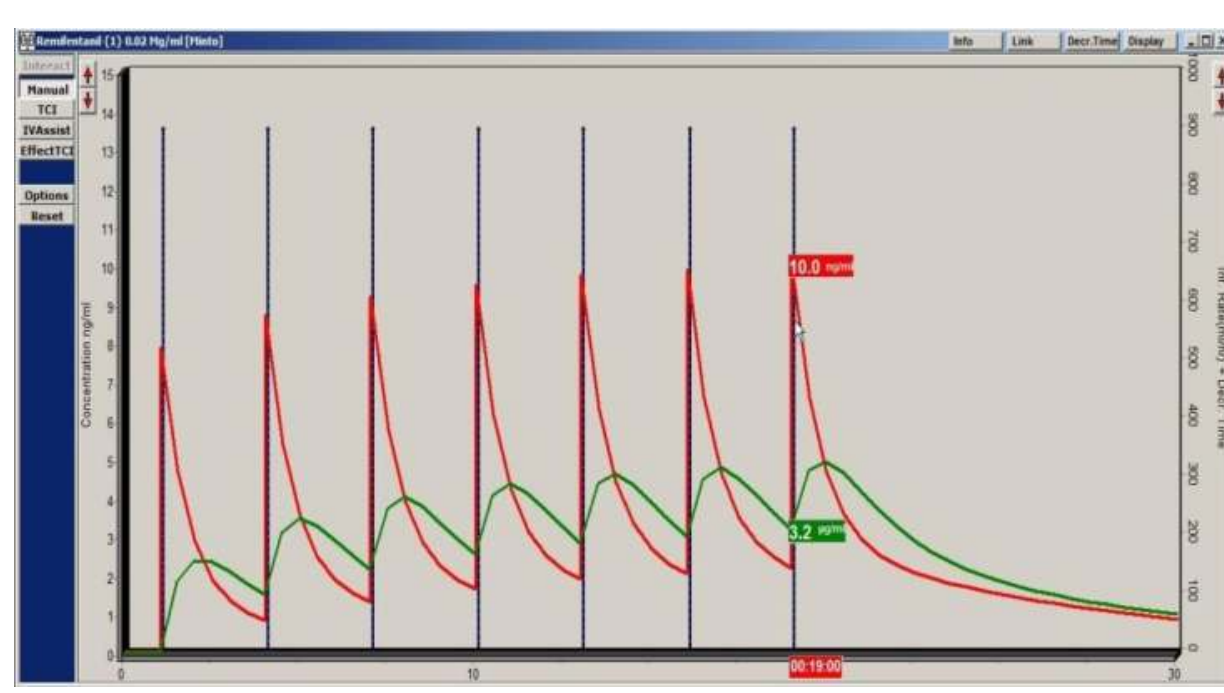

Figure 3) Plasmatic concentration Bonner et al. (Minto model)

Keywords: remifentanil, labour analgesia, patient controlled analgesia, cardiac arrest, peripartum resuscitation

\section{REFERENCES:}

Bonner, J.C., McClymont, W. Respiratory arrest in an obstetric patient using remifentanil patient-controlled analgesia. Anaesthesia, 67, 2012
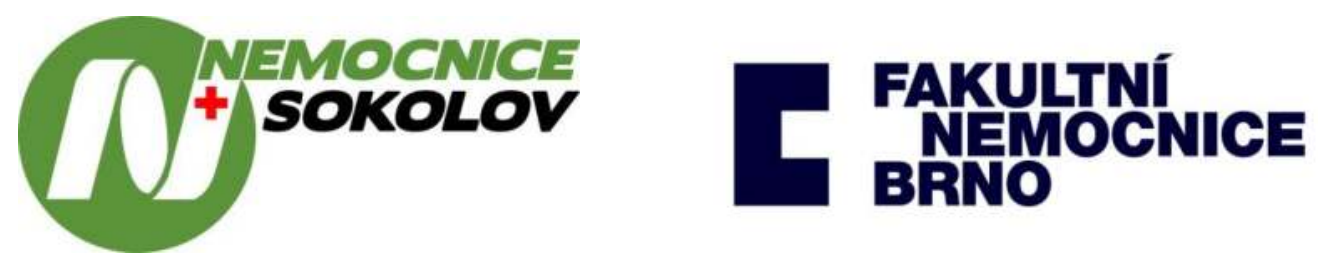